\title{
Hearing Loss In Children with Otitis Media and Effusion (OME)
}

\author{
Safaa Khalaf Faleh \\ Email :saffaakhalaf@yahoo.com.
}

\section{Thenoon Yaseen Abdulkuder}

\begin{abstract}
Otitis media with effusion (OME) is a common condition affecting children ,if not managed appropriately may lead to a serious complications.

Our study was planned to measure the pure tone audiometry and tympanometry findings in OME regarding the type and the degree of hearing loss. The study include 50 patients with age range from 4-15 years old of different gender. The thresholds in the involved cases (conductive deafness) were $31 \mathrm{dBHL}$ in the ranging between $(0-50) \mathrm{dBHL} .500 \mathrm{~Hz}$ is the frequency mostly affected, $2000 \mathrm{~Hz}$ most less affected. In bone hearing threshold (sensorineural problem), the frequency $1000 \mathrm{~Hz}$ is mostly affected, while the least affected was $250 \mathrm{~Hz}$.
\end{abstract}

\section{Keywords}

.Hearing loss, children, OME

*MBChB ,FICMS ,Otolaryngologist, Al Fayhaa General Hospital, Basrah, IRAQ. ** .. MBChB ,FICMS ,Otolaryngologist, Al Basra General Hospital, Basrah, IRAQ. Correspondence: Safaa Khalaf Faleh, ABSTRACT

\section{Introduction}

According to definition provided by Mawson (1976), Otitis media with effusion (OME) is defined as a liquid in the middle ear cavity without signs \& symptoms of infection (1). This type of otitis media is characterized by it's chronicity with a mucous or sero-mucous effusion due to local inflammation and epithelial metaplasia that last for three months or more ${ }^{(2)}$. The prevalence of OME is in a range of $80-90 \%$ in children with a seasonal variation, maximum in winter and a minimum in summer ${ }^{(3)}$ The diagnosis of OME is difficult because the process is often asymptomatic, so-called silent otitis media (4). Several investigators have shown that a high incidence of persistent middle ear effusion after an episode of acute otitis media ${ }^{(5)}$. In OME, the middle ear cavity filled with fluid that reduces drum mobility, this consequently lead to conductive problems (6), conductive impairment is maximal with lower frequencies ${ }^{(7)}$. In a screening data shows that $17-41 \%$ of children aged 2-3 years get OME during three months screening ${ }^{(8)}$. Many studies have founded that 20- 
$50 \%$ of children will suffer from OME ,at some time during 3 to 10 years old ${ }^{(6)}$. The Eustachian tube has the functions of pressure regulation, protection and clearance ${ }^{(4)}$. Eustachian tube is mostly blamed in the development of OME, Eustachian tube dysfunction present when the tube is not opened properly, not patent, or blocked by another cause ${ }^{(9)}$. Eustachian tube blockage may be the result of either intra or extra tubal forces that impede tubal opening (8). Cleft palatine anomalies, craniofacial anomalies, pediatric immune deficiencies, ciliary dyskinesia, adenoid hypertrophy, sinopathy \& children with Down syndrome may develope otitis media in general ,including with effusion ${ }^{(10)}$.

OME has different degrees of hearing problems and no very clear evidence about the correlation the effect of intermittent or long-lasting hearing difficulty with speech, language problems later on in life ${ }^{(11)}$. OME related hearing loss effect on language, speech \& cognitive milestone impairment is greatly controversial issue. Studies show conflicting results \& long-term adverse effects in the typical patient are likely to be subtle at most ${ }^{(12)}$. Some studies demonstrate evidence that even minimal or mild hearing losses in young children can impair speech and language development, \& because a child cannot hear, he is likely to be labeled 'disobedient' or ' inattentive' both at home $\&$ at school ${ }^{(13)}$. The problem is often first noticed by a schoolteacher or visiting relative, but many cases are only discovered during routine audiometric screening ${ }^{(14)}$. Different strategies used in control of OME which include nasal autoinflation, medical remedies like antihistamines, decongestants and corticosteroids and antibiotics.the surgical measures include myringotomy,adenoidectomy

and ventilation tube insertion. ${ }^{(15)}$

The aim of the study was to study the types, intensity and the frequency affected in otitis media with effusion (OME).

\section{Patients and Methods}

The study was conducted in Basrah Teaching Hospital. Fifty patients were clinically diagnosed with otitis media with effusion (OME) between October 2016 to October 2018 (28 males \& 22 females). The reviewed data in the questionnaire form were age, sex, residence, duration of the disease, hearing impairment, speech delay, school delay, and ear fullness. Age of the patients in the study ranged 4-15 years old. A control group of 24 healthy children matched in age and sex with studied group (48 ears) (age \& gender-matched) healthy persons were chosen randomly. Diagnosis was relying on several factors includes history, clinical symptoms \& signs where hearing impairment was the most important and most common symptom, microscopic \& otoscopic examination proof cabinet with help of pneumatic otoscope (the microscope used in our study was Hallpike Blackmore ear microscope \& Karl Zeiss ear microscope), pure tone audiometry (PTA), tympanometry \& myringotomy with aspiration. Cases with causes other than OME were excluded (congenital hearing loss, chronic suppurative otitis media) .

Audiometry was done using the audiometer Ittera 2 device (manufactured by GN otometrics Madsen-Denmark, Serial Number 183422 with specifications arranged according to American National Standards Institute for measurements (ANSI s3.6 1996). The tympanometry was performed using otoflix 100 tympanometer manufactured by GN 
ISSN (Print):1992-92 18, ISSN (Online):1992-92 18

DOI: https://doi.org/10.32792/utq/utjmed/19/1/12

otometrics Madsen Company -

Denmark, Serial Number 183423. Both

were done in a sound proof condition.

\section{Results}

Age of the patients in our study ranged from 4-15 years old, and the results showed that the most frequent age group affected was sixth years old then the fifth years old, the average age was 7.5 years old (table 1 ).

Table (1) Distribution of patients with OME according to age

\begin{tabular}{|l|r|r|r|r|r|r|r|r|r|r|r|r|r|}
\hline Age(year) & $\mathbf{4}$ & $\mathbf{5}$ & $\mathbf{6}$ & $\mathbf{7}$ & $\mathbf{8}$ & $\mathbf{9}$ & $\mathbf{1 0}$ & $\mathbf{1 1}$ & $\mathbf{1 2}$ & $\mathbf{1 3}$ & $\mathbf{1 4}$ & $\mathbf{1 5}$ & \\
\hline Number & 5 & 8 & 10 & 7 & 5 & 2 & 4 & 1 & 4 & 2 & 1 & 1 & $\mathbf{5 0}$ \\
\hline$\%$ & $\mathbf{1 0}$ & $\mathbf{1 6}$ & $\mathbf{1 0}$ & $\mathbf{1 4}$ & $\mathbf{1 0}$ & $\mathbf{4}$ & $\mathbf{8}$ & $\mathbf{2}$ & $\mathbf{8}$ & $\mathbf{4}$ & $\mathbf{2}$ & $\mathbf{2}$ & \\
\hline
\end{tabular}

Regarding tympanometry, our results showed that, $94 \%$ of cases are type B, $6 \%$ are type C . The targets of our study (patients) were classified into five subgroups according to duration of the disease. Table (2) shows the distribution of patients according to duration of the disease. Most of the cases submitted in our study were more than 10 months at time of diagnosis.

Table (2) Duration of the disease at time of diagnosis

\begin{tabular}{|l|l|l|l|l|l|l|}
\hline $\begin{array}{l}\text { Unknown } \\
\text { (months) }\end{array}$ & $\mathbf{1 - 3}$ & $\mathbf{6 - 4}$ & $\mathbf{7 - 9}$ & $\mathbf{> 1 0}$ & unknown & \\
\hline Number & 14 & 10 & 44 & 20 & 2 & 50 \\
\hline$\%$ & 28 & 20 & 88 & 40 & 4 & \\
\hline
\end{tabular}

Regarding the conductive deafness, our results showed that the average of air conduction thresholds were 31dBHL in the range between (0-52) dBHL, (table 3).

Table (3) distribution according to average of air conduction threshold

\begin{tabular}{|l|l|l|l|l|}
\hline Range(dB) & $\mathbf{0 - 2 0}$ & $\mathbf{2 1 - 4 0}$ & $>\mathbf{4 0}$ & \\
\hline Number & 28 & 40 & 32 & 100 \\
\hline$\%$ & 28 & 40 & 32 & \\
\hline
\end{tabular}

We found four cases of mixed SNHL, which was considered to be etiologically related to OME ( $8 \%$ of our study), where there was no family history of hereditary deafness, or history of ototoxic drugs, trauma or craniofacial abnormalities, (table 4). 
ISSN (Print):1992-92 18, ISSN (Online):1992-92 18

DOI: https://doi.org/10.32792/utq/utjmed/19/1/12

Table (4) distribution according to average of bone conduction threshold

\begin{tabular}{|l|c|c|c|}
\hline Average (dB) & $\mathbf{0 - 1 0}$ & $11-20$ & $>20$ \\
\hline$\%$ & 72 & 20 & 8 \\
\hline
\end{tabular}

The average of air conduction

threshold in each frequency, we found the frequency $2000 \mathrm{~Hz}$ was the least affected one $\& 500 \mathrm{~Hz}$ was the most affected frequency, (table 5).

Table (5) The average of air conduction threshold in each frequency

\begin{tabular}{|l|l|l|l|l|l|l|l|}
\hline $\begin{array}{l}\text { Frequenc } \\
\text { Y(Hz) }\end{array}$ & $\mathbf{2 5 0}$ & $\mathbf{5 0 0}$ & $\begin{array}{l}\mathbf{1 0 0} \\
\mathbf{0}\end{array}$ & $\begin{array}{l}\mathbf{2 0 0} \\
\mathbf{0}\end{array}$ & $\begin{array}{l}\mathbf{4 0 0} \\
\mathbf{0}\end{array}$ & $\begin{array}{l}\mathbf{8 0 0} \\
\mathbf{0}\end{array}$ & \\
\hline $\begin{array}{l}\text { Average } \\
\text { in dB }\end{array}$ & 31 & 33.4 & 33.2 & 24.4 & 29.8 & 32 & 31 \\
\hline
\end{tabular}

The average of bone conduction threshold in each frequency, we found the frequency 1000 $\mathrm{Hz}$ was mostly affected one, (table 6).

Table (6) The average of bone conduction threshold in each frequency

\begin{tabular}{|r|r|r|r|r|r|r|}
\hline Frequency $(\mathrm{Hz})$ & 250 & 500 & 1000 & 2000 & 4000 & \\
\hline Average in $(\mathrm{dB})$ & 6.2 & 7.1 & 11 & 7 & 9 & 9 \\
\hline
\end{tabular}

In comparison with above results, after performing pure tone audiogram in healthy individuals (control group) showed that the average of air conduction threshold was $10 \mathrm{~dB}$ $\&$ the average of bone conduction threshold was $9 \mathrm{~dB}$.

\section{Discussion}

This study indicate that OME was commonly associated with audiological changes. Many cases were excluded for inconvenience due to uncooperation of the patient or due to uncertain diagnosis. Although most cases affected by OME were below this age but they were unsuitable to do pure tone audiogram. There are many controversies regarding pathogenesis, audiological changes \& the treatment of OME, but still, it is considered as one of the most common causes of hearing impairment in children, in addition OME may progress to a permanent chronic inflammatory diseases
\& this is common especially with children.

In our study, in contrast to acute otitis media, we found that the clinical manifestations of this condition in children were subtle which delay consultation of the physician especially in our communities as well as the underestimation of the problem by many doctors. The conductive deafness in OME results from disturbance of middle ear mechanism by preventing the motion of the ossicles.

Sensorineural Hearing Loss (SNHL) in $\mathrm{OME}$ is known to occur in various types 


\section{ISSN (Print):1992-92 18, ISSN (Online):1992-92 18}

DOI: https://doi.org/10.32792/utq/utjmed/19/1/12

of otitis media. Although the mechanism by which SNHL develops in association with (OME) is unknown accurately, SNHL was found to be associated with chronic OME. A retrospective study in Japan revealed 14 cases( 1 percent ) of SNHL based on clinical history.in five of these cases the hearing loss was acute in onset, with subsequent recovery, while the rest showed progressive loss with out any long term improvement ${ }^{(16)}$. several hypotheses have been advocated up to now like: Paparella (1980) assumes that some noxious agents, for example bacterial products such as endotoxins, might enter to the inner ear via the round window membrane and exhibit their ototoxicity ${ }^{(17)}$.

Yellon (1994) suggested the Quinolinic acid (QUIN) (is an endogenous metabolite) it produce a neurotoxic effect by binding to specific neural receptors, (QUIN) was found in the middle ear effusions has the potential to cross the round window membrane and cause SNHL, possibly by binding to specific neural receptors in mammalian cochleae (18). Another explanation that collection of fluid in the middle ear may lead to reduction in oxygen diffusion to the inner ear through the round window membrane and distorting the cochlear function, in this connection; it has been shown that oxygen concetration of the scala tympani depending on middle ear, drops under the condition of OME. SNHL might be the result of impairment of the vibratory movements of the oval and or round windows as a consequence of the presence of effusion. ventilation tubes has eliminates this phenomenon in three cases out of four cases in our study. SNHL improvement was not achieved in one case, neither after medical treatment nor following insertion of ventilation tubes, and this might be due to the permanent damage caused by OME or e due to other causes not related to this disease. Numerous short observation intervals are needed to accurately record the onset \& the duration of OME, as the natural history is one of resolution.

In Comparison With Other Studies, T. J. Fria (1985) Demonstrated That The Average Of Air Conduction Threshold Was $27 \mathrm{db}$, \& There Were $35 \%$ Of Cases Within Normal Hearing, $45 \%$ Of Cases Had Mild Conductive Hearing Impairment \& 20\% Had Moderate Conductive Deafness, While The Average Of Bone Conduction Threshold Was 8db. In Study Of Thrasher (2007), The Average Of Air Conduction Threshold Was $28 \mathrm{db} \&$ There Were $30 \%$ Of Cases Within Normal Hearing, 50\% Of Cases Had Mild Conductive Deafness \& 20\% Had Moderate Conductive Deafness, \& Most Of These Results Were Close To The Results Of Our Study (19).

\section{Conclusions}

Otitis Media With Effusion (OME) Was The Most Common Cause Of Hearing Impairment Among Children \& Usually Of Conductive Type, Low Frequencies Were Affected More Than High Frequencies And The Frequency $500 \mathrm{~Hz}$ Was The Most Affected One. Although, OME Is A Middle Ear Cleft Disease But Can Cause Sensorineural Hearing Loss (SNHL) And The Frequency $1000 \mathrm{~Hz}$ is the most affected one. 
Web Site: https://jmed.utq.edu.iq

Email:utjmed@utq.edu.iq

ISSN (Print):1992-92 18, ISSN (Online):1992-92 18

DOI: https://doi.org/10.32792/utq/utjmed/19/1/12

\section{$\underline{\text { References }}$}

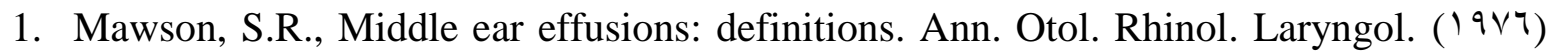
$85,12-14$

2. Pauline Vanneste, Cyril Page. Otitis media with effusion in children: Pathophysiology, diagnosis, and treatment. Journal of Otology 14 (2019) 33-39

3. Zernotti et al. Otitis media with effusion and atopy: is there a causal relationship? World Allergy Organization Journal. (2017) 10:37, DOI 10.1186/s40413-017-0168-x

4. Rinaldo G, Canalis F, Paul R. The ear comprehensive otology, 2004; vol 6:pp 383-391.

5. Byron J. Baily. H\&N surgery-otolaryngology, second edition .1998:pp 1297-1309.

6. Bruce W Jafeck. ENT secrets, 3rd edition.2005 : pp. 67-71.

7. John B Booth. Scott-Brown's otolaryngology sixth edition.1997;pp 3/1/17, 3/3/10.

8. LEE K.. Essential otolaryngology head \& neck surgery, Eighth edition. 2003 : pp 479484

9. Stanley A Gelfand. Essentials audiology.1997: pp186-194.

10. Mary N, Tally Bowden. Otolaryngology \& facial plastic surgery, second edition.2006 :pp 12 .

11. George A Gates. Current therapy in otolaryngology \& $\mathrm{H} \& \mathrm{~N}$ surgery, sixth edition.1988:pp 12.

12. Charles W Cummings..Cummings otolaryngology H\&N surgery , $4^{\text {th }}$ edition. 2000: pp 320.

13. Gerard M. O'Doghue, Grant J Bates, Antony A. Narula. Otology ,second edition. 1992:pp 63-65.

14. Martin, Burton. Hall \& Colman's diseases of the ear, nose \& throat, Fifteenth edition .2000: pp3840. 


\section{ISSN (Print):1992-92 18, ISSN (Online):1992-92 18}

DOI: https://doi.org/10.32792/utq/utjmed/19/1/12

15. Roderick P Venekamp et. al. Antibiotics for otitis media with effusion in children( review). Cochrane Database of Systematic Reviews (2016), Issue 6: 1-78 Art. No.: CD009163. DOI: 10.1002/14651858.CD009163.pub3

16. Michael Chi, Fai Tong and C Andrew Van Hasselt. Scott - Brown's Otolaryngology, seventh edition ,2007; Volume 3,chap.237b:3391.

17. PaparellaM. Inner ear pathology \& otitis media,1980;4:pp 294, 253.

18. Yellon R, Rose E. SNHL from quinolinic acid a neurotoxin in middle ear effusions. Laryngoscope ,1994 :pp176- 181.

19. Thomas J Fria. Hearing acuity of children with otitis media with effusion, Arch otolaryngol,1985;Volume 111(1):pp 6-10. 
ISSN (Print):1992-92 18, ISSN (Online):1992-92 18

DOI: https://doi.org/10.32792/utq/utjmed/19/1/12

\section{فقدان السمع عند الأطفال المصابين بالتهاب الاذن الوسطى الانصبابي}

FICMS

FICMS
د. صفاء خلف فالح اخصائي انف واذن وحنجرة د. ذنون ياسين عبا الخضر اخصائي انف واذن وانف وحنجرة

خلقية" البحهُ: التهاب الاذن الوسطى الانصبابي من الامراض الشائعة عند الأطفال، اذا لم يعالج

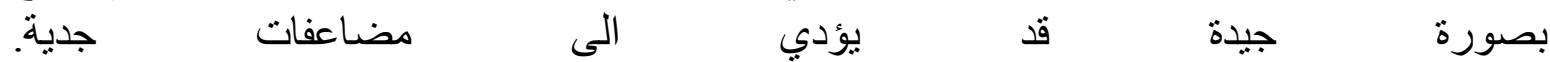
الهوف : هو إيجاد النوع ، القوة والتردد المتاثر في التهاب الاذن الوسطى الانصبابي عند الأطفال. اشخاص وطريقة الار اسة : أجريت هذه الدر اسة في مستشفى البصرة التعليمي للفترة من أكتوبر

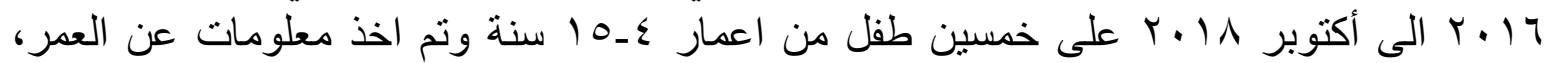

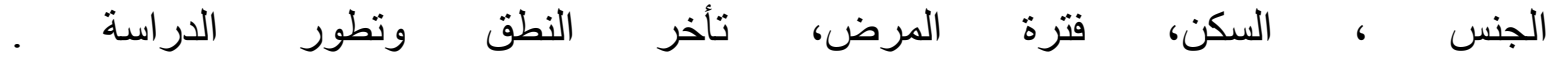

وفحص المرضى سريريا بناظور الاذن و الميكروسكوب ثم تم قياس السمع بواسطة جهاز فحص

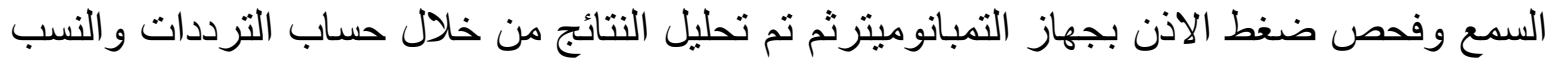

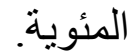

التثنائج:العمر الأكثر ناثر هو عمر 7 سنوات ومعدل العمر V,0 سنة فيما يخص فحص ضغط الاذن

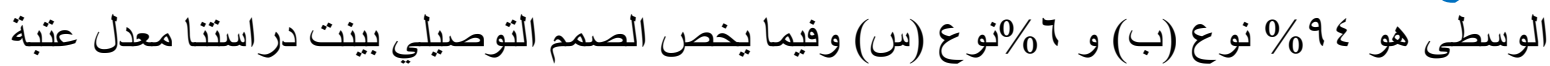
سمع هو ائي اب و وجدنا اربع حالات مع فقدان سمعي مختلط والتي تعتبر سببيا ذات علاقة وفي بالتهاب الانصبابي.

الاستثنتاجات:التهاب الاذن الوسطى الانصبابي كان السبب الأكثر شيوعا لفقدان السمع عند الأطفال

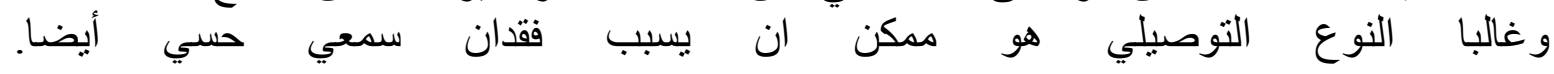

